\title{
Genetic Analysis of Conjugational Recombination in Escherichia coli K12 Strains Deficient in RecBCD Enzyme
}

\author{
By ROBERT G. LLOYD, * CAROL BUCKMAN AND FIONA E. BENSON \\ Department of Genetics, University of Nottingham, Nottingham NG7 2RD, UK
}

(Received 5 March 1987)

\begin{abstract}
Conjugational recombination in Escherichia coli was investigated by comparing the effects of recN, recO, ruv and lexA mutations on the formation of recombinants in crosses with strains lacking RecBCD enzyme. The results presented reveal that recN and ruv mutations do not abolish residual recombination in a $\operatorname{rec} B$ mutant, and have only a rather modest effect on recombination in $\operatorname{rec} B C s b c A$ strains; in these respects they are quite different from $r e c F$, recJ and $r e c O$ mutations. The differences between these two groups of genes are discussed in relation to the molecular exchanges needed to produce viable recombinants.
\end{abstract}

\section{INTRODUCTION}

During conjugation between $\mathrm{Hfr}$ and $\mathrm{F}^{-}$strains of Escherichia coli, a single strand of DNA with a $5^{\prime}$ end leading from oriT of the integrated $\mathrm{F}$ plasmid is transferred to the recipient cell where it probably serves as a template for DNA synthesis (Willetts \& Wilkins, 1984). Transfer usually terminates prematurely, releasing a DNA fragment composed of the proximally transferred half of the F plasmid linked to a variable length of the Hfr chromosome. The $3^{\prime}$ terminus probably remains single-stranded due to the lagging-strand nature of complementary DNA synthesis. Recombination between the Hfr DNA and the recipient chromosome occurs with high efficiency and shows an absolute requirement for RecA protein (Clark \& Margulies, 1965; Howard-Flanders \& Theriot, 1966) which is known to catalyse homologous pairing and strand exchange between duplex DNA molecules provided at least one of these contains a region that is single-stranded (Radding, 1982).

The efficient recovery of recombinants also requires the activities of $\operatorname{rec} B$ and $\operatorname{rec} C$. These genes provide subunits of RecBCD enzyme (Hickson et al., 1985; Amundsen et al., 1986), a DNA helicase and exonuclease that has the ability to unwind molecules with blunt, or nearly blunt, duplex ends and in doing so to nick the DNA at specific sequences called Chi (Taylor \& Smith, 1985; Taylor et al., 1985; Ponticelli et al., 1985). The requirement for RecBC can be circumvented in certain lysogenic strains by mutations $(s b c A)$ of the Rac prophage that activate synthesis of exonuclease VIII, the product of recE (Barbour et al., 1970; Kushner et al., 1974; Willis et al., 1985) or in the absence of Rac by mutation of both $s b c B$, the structural gene for exonuclease I (Kushner et al., 1971, 1972) and $s b c C$ (Lloyd \& Buckman, 1985). Recombination in $r e c B C s b c B C$ strains depends on $r e c F$ (Horii \& Clark, 1973), recJ (Lovett \& Clark, 1984), recN (Lloyd et al., 1983), recO (Kolodner et al., 1985), recQ (Nakayama et al., 1984), and ruv (Lloyd et al., 1984). Furthermore, it is reduced by mutations in lex $A\left(\mathrm{Ind}^{-}\right)$that prevent expression of the SOS response (Lloyd \& Thomas, 1983; Lovett \& Clark, 1983; Walker, 1984), an effect which is related to the fact that recN, ruv and recQ, are inducible genes regulated by LexA protein (Shurvinton \& Lloyd, 1982; Lloyd et al., 1983; Picksley et al., 1984b, Irino et al., 1986). $\operatorname{rec} B C s b c A$ strains require at least $\operatorname{rec} F$ and $\operatorname{rec} J$ (Lovett \& Clark, 1984), in addition to recE (Gillen et al., 1981). Mutation of any one of these genes has little or no effect on the efficiency of recombinant formation in matings with $\mathrm{recB}^{+} \mathrm{recC}^{+}$strains (op. cit.). 
In this paper, we describe a further analysis of conjugational recombination in which we examined the effect of $r e c N$, recO, ruv and lexA mutations on the formation of recombinants in both $s b c^{+}$and $s b c^{-}$strains lacking RecBCD activity.

\section{METHODS}

The E. coli K12 strains used are listed in Table 1. Genotype designations are those of Bachmann (1983). UV, MC, $\mathrm{Km}, \mathrm{Tm}$ and $\mathrm{Tc}$ are used to describe the response to ultraviolet light, mitomycin $\mathrm{C}$, kanamycin, trimethoprim and tetracycline, respectively. The Tn10 insertions first identified in strains N3072, N3071 and N3074 were located to $\operatorname{rec} A, \operatorname{rec} B$ and $\operatorname{rec} C$, respectively, by their cotransducibility with $s r l$ or $t h y A$ and by complementation studies using cloned $\mathrm{rec} \mathrm{A}^{+}, \mathrm{rec} B^{+}$and $\mathrm{rec} \mathrm{C}^{+}$genes (unpublished work). recC266::Tn 10 confers a more extreme recombination deficient phenotype than the classical recC22 allele (Table 2). The presence of mutant rec alleles in the strains constructed was deduced from the sensitivity of these strains to UV light or mitomycin C, or by their recombination deficiency. The genotype of multiple rec mutants was confirmed by $P 1$ transduction of the relevant alleles to $r e c^{+}$, $r e c B C s b c A$ or $\operatorname{rec} B C s b c B C$ recipients, as required for their detection.

LB broth and agar, and 56/2 minimal salts media have been described by Lloyd et al., 1974. LB media contained sodium chloride at $0.5 \mathrm{~g} \mathrm{l}^{-1}$ except for matings when the concentration of salt was raised $1010 \mathrm{~g} \mathrm{l}^{-1}$. Methods for strain construction by Plvir transduction, and for detecting sensitivity to UV light and mitomycin C have been cited by Lloyd \& Buckman, 1985 as have procedures for mating $\mathrm{F}^{-}$strains with $\mathrm{Hfr}$ or F-prime donors in broth medium, measuring zygotic induction of prophage $\lambda$, determining the numbers of viable cells in the recipient cultures used, and for selecting recombinants or F-prime transconjugants.

\section{RESULTS AND DISCUSSION}

Recombination was investigated in three closely related genetic backgrounds, all of which lacked RecBCD enzyme. The first carried $r e c B 268$, a Tn 10 insertion that reduces recombination by about the same amount as the classical recB2I allele (Table 2). recB2I is an insertion of $1.5 \mathrm{~kb}$ in $\operatorname{rec} B$ which is polar on the adjacent $\operatorname{rec} D$ gene and therefore eliminates both the $\mathrm{B}$ and the $\mathrm{D}$ subunits of RecBCD enzyme (Amundsen et al., 1986). We assume that a $\mathrm{Tn} 10$ insertion has the same effect. The second carried $\operatorname{recB} 21$ recC $22 \mathrm{sbcA23}$ and the third recB21 recC22 sbcB15 sbcC201. Recombination was measured by means of standard $\mathrm{Hfr}$ matings. Zygotic induction of prophage $\lambda$ and recovery of F-prime transconjugants in crosses with strains Hfr GY2200 and the F128 donor, KL548, respectively, provided measures of DNA transfer. Matings with $\operatorname{recA}, \operatorname{rec} \mathrm{N}, \operatorname{recO}, \mathrm{ruv}$ and $\operatorname{lexA}$ single mutants were included as controls. The data obtained are shown in detail in Table 2. The yields of recombinants obtained in crosses with Hfr strains KL226 and AB259 gave similar estimates of the recombination proficiency of mutant strains relative to the $\mathrm{rec}^{+}$control strain, AB1157. Data from these two crosses were therefore pooled to provide a mean estimate which we present separately in Table 3 to make comparisons between recipient strains easier.

\section{Residual recombination in $\mathrm{rec} B$ strains}

Mutations in $r e c B$ or $r e c C$ that inactivate $\operatorname{RecBCD}$ reduce the number of recombinants recovered from $\mathrm{Hfr}$ crosses to about $1 \%$ of the normal yield. Previous studies revealed that this residual capacity for recombination depends on recF and recJ (Gillen \& Clark, 1974; Gillen et al., 1981; Lovett \& Clark, 1984). In our hands, $r e c F$ and $r e c J$ mutations were found to reduce the ability of a $\mathrm{rec} B$ strain to form recombinants by factors of about 8-fold and 20 -fold, respectively (data not shown). The results presented in Table 3 show that a rec $O$ mutation has a similar effect. $A \mathrm{rec} B \mathrm{rec} O$ double mutant was found to produce hardly any more recombinants than a rec $A$ strain (Table 2). In contrast, recN and ruv mutations appeared to have little or no effect on recombination in a $\operatorname{rec} B$ strain. Given that $\operatorname{rec} N$ and $r u v$ single mutants are slightly deficient in recombination, it is clear from the results presented that recB recN and recB ruv double mutants are no more deficient than a $\operatorname{rec} B$ single mutant. Since the production of recombinants was also largely unaffected by introducing a lex $A\left(\right.$ Ind $\left.^{-}\right)$mutation, it seems unlikely therefore that the residual recombination observed in a $\operatorname{rec} B$ mutant is related to the activity of LexA regulated genes. This would be consistent with the fact that introduction of a lexA(Def) mutation to increase expression of LexA regulated genes (Walker, 1984) failed to increase recombination in 
Table 1. E. coli K12 strains

Strain Relevant genotype* Other markers

\begin{tabular}{|c|c|}
\hline AB 1157 & $r e c^{+} s b c^{+}$ \\
\hline AB2470 & $\operatorname{recB2l}$ \\
\hline JC5489 & $\operatorname{recC} 22$ \\
\hline JC7623 & $\operatorname{rec} B C s b c B C$ \\
\hline JC8679 & $\operatorname{rec} B 21 \operatorname{rec} C 22 s b c A 23$ \\
\hline RDK1541 & $\operatorname{rec} 01504:: \mathrm{Tn} 5$ \\
\hline DM49 & $\operatorname{lex} A 3\left(\right.$ Ind $\left.^{-}\right)$ \\
\hline DM1420 & lexA5I(Def) \\
\hline HI24 & $\operatorname{ruv} A 4$ \\
\hline CS85 & $r u v-53$ \\
\hline CS86 & $r u v-54$ \\
\hline CS140 & $r u v-53$ \\
\hline SP254 & $\operatorname{recN} 262$ \\
\hline SP256 & tyra16:: $\operatorname{Tn} 10$ rec $N 262$ \\
\hline FB288 & rec $B C$ sbcA23 recAo254 \\
\hline $\mathrm{N} 3100$ & recA $269:: \operatorname{Tn} 10$ \\
\hline N3071 & $\operatorname{recB} 268:: \operatorname{Tn} 10$ \\
\hline N3072 & $\operatorname{rec} A 269:: \operatorname{Tn} 10$ \\
\hline N3074 & $\operatorname{rec} C 266:: \operatorname{Tn} 10$ \\
\hline N1434 & recAo254 \\
\hline N1627 & recA200 srl-1300:: Tn 10 \\
\hline N1630 & lexA3 malE ::Tn5 \\
\hline $\mathrm{N} 1642$ & lexA3 male $:: \operatorname{Tn} 10$ \\
\hline $\mathrm{N} 1824$ & $\operatorname{lex} A 51$ \\
\hline N1844 & $\operatorname{lexA5I}$ \\
\hline N 1845 & lexA51 recB21 \\
\hline $\mathrm{N} 2101$ & $\operatorname{recB} 268:: \operatorname{Tn} 10$ \\
\hline $\mathbf{N} 2103$ & $\operatorname{recC} 266:: \operatorname{Tn} 10$ \\
\hline $\mathrm{N} 2105$ & lex $A 3$ rec $B 268:: \operatorname{Tn} 10$ \\
\hline $\mathrm{N} 2113$ & $\operatorname{recN} 262 \operatorname{recB} 268:: \operatorname{Tn} 10$ \\
\hline N2117 & ruvA4 recB268:: Tn 10 \\
\hline $\mathrm{N} 2133$ & $r u v-53 \operatorname{rec} B 268:: \operatorname{Tn} 10$ \\
\hline $\mathrm{N} 2232$ & $\operatorname{rec} B C s b c B C$ lex $A 3$ \\
\hline N2237 & recBC sbcBC recN262 \\
\hline $\mathrm{N} 2242$ & recBC sbc $A 23$ ruv-53 \\
\hline N2244 & recBC sbcA23 ruv-54 \\
\hline N2249 & $\operatorname{rec} B C \operatorname{sbc} A 23$ lexA3 \\
\hline N2254 & recBC $s b c A 23$ recN 262 \\
\hline $\mathrm{N} 2283$ & $\operatorname{rec} B C \operatorname{sbc} B C \operatorname{rec} A o 254$ \\
\hline N2286 & rec $B C s b c B C$ rec Ao 254 lex $A 3$ \\
\hline N2291 & $\operatorname{rec} B C \operatorname{sbcBC}$ rec Ao 254 \\
\hline $\mathrm{N} 2292$ & rec $B C$ sbcBC rec $A \circ 254$ recN 262 \\
\hline $\mathrm{N} 2445$ & recol $01504:: \operatorname{Tn} 5$ \\
\hline $\mathrm{N} 2447$ & reco1504:: $\operatorname{Tn} 5$ recB $268:: \operatorname{Tn} 10$ \\
\hline $\mathrm{N} 2510$ & recBC sbcA23 reco1504:: $\mathrm{Tn} 5$ \\
\hline $\mathrm{N} 2551$ & $\operatorname{rec} B C s b c A 23$ rec $A o 254$ \\
\hline $\mathrm{N} 2552$ & recBC sbcA23 recAo 254 lexA3 \\
\hline N2554 & recBC sbc $A 23$ rec $A o 254$ rec N262 \\
\hline KL548 & $\begin{array}{l}\mathrm{F}(128) \text { proAB } B^{+} \text {lacI3 lacZ813/ } \\
\Delta(\text { pro-lac }) \chi 111\end{array}$ \\
\hline KL226 & $\mathrm{HfrC}(\mathrm{PO} 2 \mathrm{~A})$ \\
\hline AB259 & Hfr (Hayes, PO1) \\
\hline GY2200 & $\operatorname{Hfr}$ (Hayes) $\left(\lambda \text { ind }^{-}\right)^{+}$ \\
\hline
\end{tabular}

$\dagger$
$\dagger$
$\dagger$
$\dagger$
$\dagger$
$\dagger$
$\dagger$, but sfiAll arg
$\dagger$
$\dagger$, eda-51::Tn10
as CS85
as CS85 but eda? $\left(\mathrm{Tc}^{\mathrm{s}}\right)$
$\dagger$
$\dagger$
$\dagger$
$\dagger$
IN $($ rrnD-rrnE)I
as $\mathrm{N} 3071$
as $\mathrm{N} 3071$
$\mathrm{~F}^{-}$lexA3
$\dagger$, but arg $^{+}$his $^{+}$
$\dagger$

\section{as DM49}

as DM1420 but thyA

as DM1420

as DM1420

$\dagger$

as DM49

$\dagger$

\section{as $\operatorname{CS} 140$}

$\dagger$ and malE:: $\operatorname{Tn} 10$

$\dagger$ and tyrA $16:: \operatorname{Tn} 10$

$\dagger$ and eda-51::Tn10

as $\mathrm{N} 2242$

$\dagger$ and malE:: $\operatorname{Tn} 5$

$\dagger$ and tyrA16:: $\mathrm{Tn} 10$

$\dagger$

$\dagger$ and malE::Tn 10

$\dagger$ and tyrA16:: $\mathrm{Tn} 10$

as $\mathrm{N} 2291$

$\dagger$

$\dagger$

$\dagger$ and malE:: $\operatorname{Tn} 10$

as N2251

$\dagger$ and tyrA $16:: \operatorname{Tn} 10$

recA rpsE
Source or derivation

Bachmann (1972)

Bachmann (1972)

Bachmann (1972)

Kushner et al. (1971)

Gillen et al. (1981)

Kolodner et al. (1985)

D. W. Mount

D. W. Mount

Otsuji et al. (1974)

Shurvinton et al. (1984)

Shurvinton et al. (1984)

Shurvinton et al. (1984)

Picksley et al. (1984a)

Picksley et al. (1984a)

$\ddagger$

P1.N3072 × AB1157 to Tc

$\S$

$\S$

Thomas \& Lloyd (1980)

$\|$

P1.(malE:: Tn5 lexA3) $\times$

$\mathrm{AB} 1157$ to $\mathrm{Km}^{\mathrm{r}}$

P1. (malE::Tn10) $\times$ DM49 to $\mathrm{Tc}^{r}$

$\mathrm{Tm}$ selection on DM1420

P1 . AB2470 $\times$ N1824 to Thy $^{+}$

P1.AB2470 $\times$ N1824 to Thy $^{+}$

P1.N3071 $\times$ AB1 157 to $\mathrm{Tc}^{r}$

P1.N3074 $\times$ AB1157 to $\mathrm{Tc}^{r}$

$\mathrm{P1} . \mathrm{N} 3071 \times \mathrm{DM} 49$ to $\mathrm{Tc}^{\mathrm{r}}$

P1.N3071 $\times$ SP254 to $\mathrm{Tc}^{r}$

P1.N3071 $\times$ HI24 to $\mathrm{Tc}^{\mathrm{r}}$

$\mathrm{P1}$. N3071 $\times$ CS140 to $\mathrm{Tc}^{r}$

P1.N1642 $\times$ JC7623 to Tc ${ }^{r}$

P1.SP256 $\times$ JC7623 to $\mathrm{Tc}^{\mathrm{r}}$

$\mathrm{P1}$. CS85 $\times \mathrm{JC} 8679$ to $\mathrm{Tc}^{\mathrm{r}}$

P1.CS86 $\times$ JC8679 to $\mathrm{Tc}^{r}$

P1.N1630 $\times$ JC8679 to $\mathrm{Km}^{\mathrm{r}}$

P1.SP256 $\times$ JC8679 to $\mathrm{Tc}^{r}$ II

$\mathrm{P} 1 . \mathrm{N} 1642 \times \mathrm{N} 2283$ to $\mathrm{Tc}^{\mathrm{r}}$

$\mathrm{P1}$. SP256 $\times \mathrm{N} 2283$ to $\mathrm{Tc}^{\mathrm{r}}$

$\mathrm{P} 1 . \mathrm{SP} 256 \times \mathrm{N} 2283$ to $\mathrm{Tc}^{r}$

Pl.RDK1541 × AB1157 to $\mathrm{Km}^{\mathrm{r}}$

P1.N3071 $\times$ RDK1541 to $\mathrm{Tc}^{\mathrm{r}}$

P1.RDK $1541 \times$ JC8679 to $\mathrm{Km}^{\mathrm{r}}$

P1.N1642 $\times$ FB288 to $\mathrm{Tc}^{\mathrm{r}}$

P1.N1642 $\times$ FB288 to $\mathrm{Tc}^{r}$

$\mathrm{P} 1 . \mathrm{SP} 256 \times \mathrm{FB} 288$ to $\mathrm{Tc}^{r}$

K. B. Low

K. B. Low

K. B. Low

R. Devoret

* $r e c B C$ is used to denote $\operatorname{rec} B 21$ recC22, and $s b c B C$ to denote $s b c B C 15$ sbcC201 (Lloyd \& Buckman, 1985). † F- thi-I his-4 $\triangle(\mathrm{gpt}$ - proA)62 argE3 thr-1 leuB6 kdgK51 rfbD1? ara-14 lac Y1 galK2 xyl-5 mtl-1 tsx-33 supE44 $\operatorname{rps} L 31$.

$\ddagger \mathrm{P} 1 . \mathrm{N} 1627 \times \mathrm{JC} 8679$ to $\mathrm{recA} 200 \mathrm{srl}-1300:: \mathrm{Tn} 10$, then $\times \mathrm{P} 1 . \mathrm{N} 1434$ to $_{\mathrm{sr}} \mathrm{l}^{+}$and $\mathrm{Rec}^{+}$at $42^{\circ} \mathrm{C}$.

$\S$ Isolated as Tn 10 insertion mutants of strain W3110 (Bachmann, 1972) by following the procedure of Silhavy $e t$ al. (1984) and screening for sensitivity to UV.

\|An srl-1300:: Tn 10 derivative of strain N1802 (Lloyd \& Thomas, 1983).

I Derived from JC7623 as for FB288. 
Table 2. Transconjugant formation and viability of recipient strains in F-prime and Hfr crosses with $F^{-}$strains carrying combinations of rec, ruv, lex $A$ and sbc mutations

Mating was for $30 \mathrm{~min}(\times \mathrm{KL} 548), 40 \mathrm{~min}(\times \mathrm{KL} 226$ and $\times$ AB259) or $60 \mathrm{~min}(\times \mathrm{GY} 2200)$. Strain AB1157 was used as the rec ${ }^{+}$control and was mated along with the mutant strains to be tested in all cases. Matings were done in parallel sets, with samples of the same recipient culture being mated with samples of each donor culture and vice versa. The number of viable cells in the recipient cultures used was determined by plating samples on non-selective 56/2 agar. Yields of transconjugants per $\mathrm{ml}$ of mating mixture for strain $\mathrm{AB} 1157$ are means of $30-40$ independent matings. Viability and transconjugant yields for other strains are given relative to $\mathrm{AB} 1157$ and are the means of the relative values obtained in at least two, but usually between three and five, independent matings.

Transconjugants per $\mathrm{ml}$ relative to strain AB1157

\begin{tabular}{|c|c|c|c|c|c|c|}
\hline $\begin{array}{l}\text { Genotype } \\
\text { tested }\end{array}$ & $\begin{array}{l}\text { Strain } \\
\text { no. }\end{array}$ & Viability & $\begin{array}{c}\times \text { KL548 } \\
\left(\text { Pro }^{+}\right)\end{array}$ & $\begin{array}{r}\times \text { GY2200 } \\
(\lambda \text { plaques })\end{array}$ & $\begin{array}{l}\text { KL226 } \\
\left(\text { Pro }^{+}\right)\end{array}$ & $\begin{array}{c}\times \text { AB259 } \\
\left(\mathrm{Thr}^{+} \mathrm{Leu}^{+}\right)\end{array}$ \\
\hline $\mathrm{rec}^{+}$ & AB 1157 & $1.9 \times 10^{8}=1.0$ & $1.5 \times 10^{7}=1.0$ & $5.6 \times 10^{6}=1.0$ & $6.7 \times 10^{6}=1.0$ & $7.6 \times 10^{6}=1 \cdot$ \\
\hline 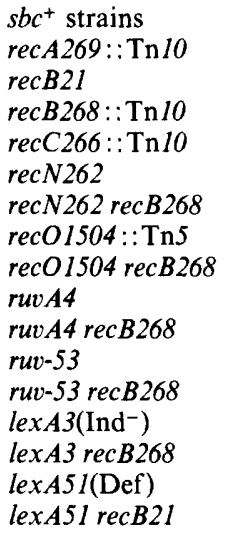 & $\begin{array}{l}\text { N3100 } \\
\text { AB2470 } \\
\text { N2101 } \\
\text { N2103 } \\
\text { SP254 } \\
\text { N2113 } \\
\text { N2445 } \\
\text { N2447 } \\
\text { H124 } \\
\text { N2117 } \\
\text { CS140 } \\
\text { N2133 } \\
\text { DM49 } \\
\text { N2105 } \\
\text { N1844 } \\
\text { N1845 }\end{array}$ & $\begin{array}{c}0 \cdot 50 \\
0 \cdot 32 \\
0 \cdot 31 \\
\text { ND } \\
1 \cdot 10 \\
0 \cdot 41 \\
1 \cdot 07 \\
0 \cdot 30 \\
0 \cdot 57 \\
0 \cdot 22 \\
0 \cdot 45 \\
0 \cdot 33 \\
0 \cdot 93 \\
0 \cdot 39 \\
\text { ND } \\
\text { ND }\end{array}$ & $\begin{array}{l}0.34 \\
0 \cdot 31 \\
0 \cdot 24 \\
0 \cdot 28 \\
0 \cdot 71 \\
0 \cdot 26 \\
0 \cdot 77 \\
0 \cdot 13 \\
0 \cdot 33 \\
0 \cdot 13 \\
0 \cdot 41 \\
0 \cdot 16 \\
0 \cdot 43 \\
0 \cdot 22 \\
0 \cdot 45 \\
0 \cdot 07\end{array}$ & $\begin{array}{c}0.46 \\
1.05 \\
0.93 \\
\text { ND } \\
0 \cdot 95 \\
0.95 \\
1 \cdot 16 \\
\text { ND } \\
0.93 \\
0 \cdot 85 \\
0.69 \\
1.0 \\
0 \cdot 75 \\
1.07 \\
0.97 \\
0.27\end{array}$ & $\begin{array}{l}0.000011 \\
0 \cdot 0027 \\
0 \cdot 0017 \\
0.0023 \\
0 \cdot 47 \\
0 \cdot 0014 \\
0 \cdot 88 \\
0 \cdot 0002 \\
0 \cdot 15 \\
0 \cdot 0019 \\
0 \cdot 27 \\
0 \cdot 001 \\
0 \cdot 24 \\
0.00095 \\
1 \cdot 13 \\
0.00081\end{array}$ & $\begin{array}{l}0 \cdot 000037 \\
0 \cdot 0012 \\
0 \cdot 00094 \\
0 \cdot 0012 \\
0 \cdot 53 \\
0 \cdot 00073 \\
0 \cdot 84 \\
0 \cdot 000067 \\
0 \cdot 29 \\
0 \cdot 0015 \\
0 \cdot 13 \\
0 \cdot 00049 \\
0 \cdot 33 \\
0 \cdot 0006 \\
1 \cdot 00 \\
0 \cdot 0015\end{array}$ \\
\hline $\begin{array}{l}\text { recB21 recC22 sbcA } \\
(\operatorname{recBC} s b c A) \\
\operatorname{rec} N 262 \\
\operatorname{rec} O 1504:: \mathrm{Tn} 5 \\
\operatorname{ruv}-53 \\
\operatorname{ruv}-54 \\
\operatorname{lex} A 3 \\
\operatorname{rec} A o 254 \\
\operatorname{rec} A o 254 \text { recN262 } \\
\operatorname{recAo254} \text { lexA3 }\end{array}$ & $\begin{array}{l}\text { JC8679 } \\
\text { N2254 } \\
\text { N2510 } \\
\text { N2242 } \\
\text { N2244 } \\
\text { N2249 } \\
\text { N2551 } \\
\text { N2554 } \\
\text { N2552 }\end{array}$ & $\begin{array}{l}0.67 \\
0.58 \\
0.34 \\
0.31 \\
0.44 \\
0.62 \\
0.57 \\
0.43 \\
0.40\end{array}$ & $\begin{array}{l}0.88 \\
0.83 \\
0 \cdot 22 \\
0.013 \\
0.038 \\
0.54 \\
0.50 \\
0.56 \\
0.24\end{array}$ & $\begin{array}{l}1.23 \\
1.33 \\
1 \cdot 17 \\
1.02 \\
1.42 \\
1.24 \\
1.22 \\
0.98 \\
1.27\end{array}$ & $\begin{array}{l}0.52 \\
0 \cdot 14 \\
0 \cdot 0039 \\
0 \cdot 061 \\
0 \cdot 13 \\
0.032 \\
0 \cdot 47 \\
0 \cdot 21 \\
0 \cdot 11\end{array}$ & $\begin{array}{l}0.82 \\
0.25 \\
0.0076 \\
0.038 \\
0.25 \\
0.082 \\
0.73 \\
0.26 \\
0.15\end{array}$ \\
\hline $\begin{array}{l}\text { recB21 recC22 sbcB } \\
(\text { rec } B C \text { sbcBC } \\
\text { rec } 262 \\
\operatorname{lex} A 3 \\
\text { rec } A o 254 \\
\text { recAo254 recN } 262 \\
\text { recAo254 lexA3 }\end{array}$ & $\begin{array}{l}\text { JC7623 } \\
\text { N2237 } \\
\text { N2232 } \\
\text { N2291 } \\
\text { N2292 } \\
\text { N2286 }\end{array}$ & $\begin{array}{l}0 \cdot 60 \\
0 \cdot 46 \\
0 \cdot 39 \\
0 \cdot 60 \\
0 \cdot 31 \\
0 \cdot 64\end{array}$ & $\begin{array}{l}0.92 \\
0.52 \\
0.37 \\
0.95 \\
0.74 \\
0.47\end{array}$ & $\begin{array}{l}0.63 \\
1.02 \\
1.18 \\
0.91 \\
0.82 \\
0.93\end{array}$ & $\begin{array}{l}0.60 \\
0.014 \\
0.002 \\
0.71 \\
0.012 \\
0.014\end{array}$ & $\begin{array}{l}0.70 \\
0.016 \\
0.004 \\
0.69 \\
0.017 \\
0.013\end{array}$ \\
\hline
\end{tabular}

* For ease of presentation, transposon insertions are sometimes abbreviated to show the gene symbol and mutant allele number only.

ND, Not determined.

a $\operatorname{rec} B$ strain (Table 3), as was reported by Lovett \& Clark (1983). A similar series of strains constructed with recB21 or recC266:: Tn 10 to inactivate RecBCD gave essentially identical findings (data not shown).

\section{Recombination in rec $B C$ sbc strains}

The efficiency of recombination in crosses with $\operatorname{rec} B C s b c A$ strains approaches that of a $\mathrm{rec}^{+} s b c^{+}$strain. Previous studies (Gillen et al., 1981; Lovett \& Clark, 1984) established that 
Table 3. Effect of recN, recO, ruv, lexA and rec Ao mutations on recombination in $\mathrm{rec} B$ and $\mathrm{rec} B C$ sbc genetic backgrounds

The mean values and standard errors (in parentheses) shown are based on the data obtained from an equal number of crosses with Hfrs KL226 and AB259 (see Table 2 for details) and are not corrected for any deficiency in DNA transfer or viability. Numbers of crosses involved are given as subscripts.

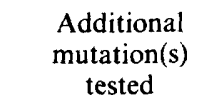

None

recO1504:: $\operatorname{Tn} 5$

$\operatorname{ruvA4}$

$r u v-53$

ruv -54

$\operatorname{rec} N 262$

$\operatorname{lex} A 3\left(\mathrm{Ind}^{-}\right)$

lexA5I(Def)

recAo 254

recAo 254 rec $N 262$

recAo 254 lexA3
Yield of recombinants relative to the $\mathrm{rec}^{+} s b c^{+}$control strain AB1157

\begin{tabular}{|c|c|c|c|}
\hline $\mathrm{rec}^{+} s b c^{+}$ & $\operatorname{rec} B 268:: \operatorname{Tn} 10$ & $\operatorname{rec} B C s b c A$ & $\operatorname{rec} B C s b c B C$ \\
\hline $1 \cdot 0$ & $0.0013(0.0002)_{6}$ & $0.73(0.08)_{10}$ & $0.65(0.05)_{10}$ \\
\hline $0.856(0.06)_{10}$ & $0.00013(0.00004)_{4}$ & $0.006(0.001)_{4}$ & \\
\hline $0.22(0.04)_{6}$ & $0.0012(0.0004)_{4}$ & & \\
\hline $0 \cdot 19(0 \cdot 05)_{4}$ & $0 \cdot 0008(0 \cdot 0002)_{4}$ & $\begin{array}{l}0.05(0.007)_{8} \\
0.19(0.04)_{4}\end{array}$ & \\
\hline \multirow{3}{*}{$\begin{array}{l}0.49(0.07)_{6} \\
0.29(0.03)_{6}\end{array}$} & $0.0011(0.0003)_{4}$ & $0.19(0.03)_{8}$ & $0.015(0.002)_{4}$ \\
\hline & $\begin{array}{l}0.0008(0.0001)_{4} \\
0.0042(0.0005)_{2}\end{array}$ & $0.057(0.015)_{4}$ & $0.003(0.0008)_{6}$ \\
\hline & & $\begin{array}{l}0 \cdot 63(0 \cdot 12)_{4} \\
0 \cdot 23(0.018)_{6} \\
0 \cdot 13(0.018)_{8}\end{array}$ & $\begin{array}{l}0 \cdot 70(0 \cdot 1)_{8} \\
0 \cdot 02(0 \cdot 002)_{4} \\
0.014(0 \cdot 0006)_{4}\end{array}$ \\
\hline
\end{tabular}

* The strain used in this case $(\mathrm{N} 1845)$ carried $\operatorname{recB} 21$ and not recB268.

recombination in this background requires $r e c A, r e c F$ and recJ. The data presented in Table 3 show that $\mathrm{rec} O$ is also needed. Mutation of $\mathrm{recO}$ reduces the yield of recombinants by more than 200 -fold, which is very similar to the effect of a recF or recJ mutation (op. cit.; R. G. Lloyd \& C. Buckman, unpublished work). However, the actual deficiency in recombination may be nearer 100 -fold since there is some 3 - to 5-fold reduction in cell viability and in the formation of F-prime transconjugants (Table 2). Mutations in recN and ruv also reduce recombination, but in each case the effect produced is not severe (Table 3). A recBC $s b c A$ recN mutant produced $25 \%$ as many recombinants as the $r e c N^{+}(\operatorname{rec} B C s b c B C)$ control strain. With recBC sbcA ruv mutants, the reduction in the yield of recombinants ranged from 4-fold (ruv-54) to 15-fold (ruv-53). Studies with strains carrying ruv-52 and ruv ::Tn 10 (Shurvinton et al., 1984) gave similar results, with the yield of recombinants from $\mathrm{Hfr}$ crosses reduced by about 3-fold and 10-fold, respectively (data not shown). It is clear from these results that the recombination deficiency of $\operatorname{rec} B C \operatorname{sbcA}$ recN and $r e c B C s b c A$ ruv strains is only some 2- to 3-fold greater than the corresponding $\operatorname{rec} N$ and $r u v$ single mutants.

We discovered that mutation of $r u v$ in a $\operatorname{rec} B C \operatorname{sbcA}$ genetic background interfered with the recovery of F-prime transconjugants. Thus, the yield of $\mathrm{Pro}^{+}$colonies obtained in crosses between KL548 (F128-pro $\left.{ }^{+}\right)$and $\operatorname{recBC} s b c A$ ruv recipients strains was at least 25 -fold lower than with the corresponding $r u v^{+}$recipient (Table 2). Since this deficiency can be alleviated entirely by making the $\operatorname{rec} B C s b c A$ ruv strain $\operatorname{rec} A$ (unpublished work), we suspect that it reflects abortive recombination between the transferred F-prime and the homologous region of the recipient chromosome in the absence of ruv function. A rec $A$ mutation would be expected to prevent the initiation of such recombination and thereby allow the F-prime to become established in the transconjugant cell.

Picksley et al. (1984b) observed that expression of recN is undetectable in the presence of a lex $A\left(\mathrm{Ind}^{-}\right)$mutation. If this is true for a $\operatorname{rec} B C \operatorname{sbc} A$ lex $A\left(\mathrm{Ind}^{-}\right)$strain, the ability to form recombinants should be reduced to the level of a $\operatorname{rec} B C \operatorname{sbcA} \operatorname{recN}$ strain at the very least, given that a lex $A\left(\right.$ Ind $\left.^{-}\right)$mutation is also expected to limit expression of $\operatorname{rec} A$, rec $Q$ and $r u v$. The data presented in Table 3 reveal that recombination is in fact reduced by a factor approaching 20fold. To see if this additional effect was due to reduced expression of $\operatorname{rec} A$, we compared the effects produced by lex $A\left(\mathrm{Ind}^{-}\right)$and $\operatorname{rec} N$ mutations in $\operatorname{rec} B C \operatorname{sbc} A$ strains carrying a $\operatorname{rec} A$ operator mutation (recAo254) to increase synthesis of RecA. The results (Table 3) reveal that the level of recombination was unaltered in the rec $N$ derivative but was increased in the lex $A\left(\mathrm{Ind}^{-}\right)$ derivative to the extent that the efficiency of recombinant formation is now essentially the same 
in both cases. The same observation was made in a $\operatorname{rec} B C \operatorname{sbc} B C$ genetic background using a similar series of $\operatorname{rec} A o, \operatorname{recN}$ and $\operatorname{lex} A\left(\mathrm{Ind}^{-}\right)$mutant derivatives, though in this case both recN and lex $A$ mutations cause a more severe deficiency in recombinant formation. A preliminary report of studies with these $\operatorname{rec} B C s b c B C$ derivatives was published by Picksley et al. $(1984 b)$. We conclude that a $\operatorname{lex} A\left(\mathrm{Ind}^{-}\right)$mutation prevents efficient recombination in both the $\operatorname{rec} B C s b c A$ and $\operatorname{rec} B C s b c B C$ genetic backgrounds by abolishing expression of $\operatorname{rec} N$ and reducing expression of $\operatorname{rec} A$, and that in this respect any reduction in the expression of ruv or $r e c Q$ does not have a major additional effect.

Recombination in a $r e c B C s b c B C$ strain is different from that operating in a $\operatorname{rec} B C \operatorname{sbc} A$ strain in that it is activated by loss of exonuclease I rather than by synthesis of exonuclease VIII. The reduced requirement for $r e c N$ and $r u v$ in the $\operatorname{rec} B C s b c A$ background is presumably a reflection of this difference. Clark et al. (1984) and Lloyd \& Thomas (1984) suggested that the single-strand overhang expected to be present at the $3^{\prime}$ terminus of the DNA transferred in Hfr crosses is normally removed by exonuclease $\mathrm{I}$, which is known to act specifically on single-stranded DNA in the $3^{\prime}-5^{\prime}$ direction. This would eliminate a substrate that might otherwise be used directly by RecA to initiate recombination. However, in $\mathrm{rec}^{+}$strains, RecBCD helicase is available to regenerate a substrate for RecA and allow recombination to proceed efficiently. The absence of exonuclease I or synthesis of exonuclease VIII to counter its effect (exonuclease VIII degrades linear DNA duplexes in the 5'-3' direction, Joseph \& Kolodner, 1983) would then enable RecA to initiate an exchange at the $3^{\prime}$ terminus without prior intervention of RecBCD. Therefore, the discovery that $r e c N$ and $r u v$ are essential for recombination in $r e c B C s b c B C$ strains but much less so in a recBC sbcA strain suggests that the products of these genes may operate to promote exchanges at the $3^{\prime}$ terminus of the Hfr DNA. One possibility consistent with their known involvement in DNA repair (Lloyd et al., 1984; Picksley et al., 1984a) is that they help to protect single-stranded DNA from further nuclease digestion. A lack of recN or ruv function would be less of a problem for $\operatorname{rec} B C s b c A$ strains since single-stranded DNA could always be replenished by exonuclease VIII.

$\mathrm{recF}$, recJ, and $\mathrm{rec} O$ are indispensable for conjugational recombination in the absence of $\mathrm{RecBCD}$ enzyme. Since these genes are also needed to promote recombination between circular plasmid molecules, whereas recBC, recN and ruv are not (Kolodner et al., 1985), we assume that their products are not restricted to linear DNA substrates with duplex ends as seems to be the case with RecBCD enzyme (Taylor \& Smith, 1985). In this sense, the RecFJO proteins may provide an alternative to RecBCD which during conjugation is able to initiate genetic exchanges well away from duplex DNA ends, possibly at transient gaps in the newly synthesized complementary strand, as suggested by Lloyd \& Thomas (1984). A recent investigation of $\beta$ galactosidase synthesis in conjugational crosses between lac $Z$ mutants has revealed that the products of recFJO do provide an alternative to $\mathrm{RecBCD}$ that can generate recombinant DNA with high efficiency (Lloyd et al., 1987).

This interpretation of the genetics of conjugational recombination leads naturally to the conclusion that the course of recombination in general in $E$. coli will be dictated by the substrates involved, and in particular on whether or not the DNA molecules have ends.

The authors are particularly grateful to those kind enough to provide some of the strains used. This work was supported in part by grants to R. G. Lloyd from the Science and Engineering Research Council.

\section{REFERENCES}

Amundsen, S. K., Taylor, A. F., Chaudhury, A. M. \& SMith, G. R. (1986). recD: The gene for an essential third subunit of exonuclease V. Proceedings of the National Academy of Sciences of the United States of America 83, 5558-5562.

Bachmann, B. J. (1972). Pedigrees of some mutant strains of Escherichia coli K12. Bacteriological Reviews 36, 525-557.

BACHMANN, B. J. (1983). Linkage map of Escherichia coli K12, edition 7. Microbiological Reviews 47, 180 230.

Barbour, S. D., Nagaishi, H., Templin, A. \& Clark, A. J. (1970). Biochemical and genetic studies of recombination proficiency in Escherichia coli. II. $\mathrm{Rec}^{+}$revertants caused by indirect suppression of $\mathrm{Rec}^{-}$mutations. Proceedings of the National Academy of Sciences of the United States of America 67, 128135. 
Clark, A. J. \& Margulies, A. D. (1965). Isolation and characterisation of recombination-deficient mutants of Escherichia coli K12. Proceedings of the National Academy of Sciences of the United States of America 53, 451-459.

Clark, A. J., Sandler, S. J., Willis, D. K., Chu, C. C., Blanar, M. A. \& Lovett, S. T. (1984). Genes of the RecE and RecF pathways of conjugational recombination in Escherichia coli. Cold Spring Harbor Symposia on Quantitative Biology XLIX, 453-462.

Gillen, J. R. \& Clark, A. J. (1974). The RecE pathway of bacterial recombination. In Mechanisms in Recombination, pp. 123-136. Edited by R. F. Grell. Plenum Publishing Corporation: New York.

Gillen, J. R., Willis, D. K. \& Clark, A. J. (1981). Genetic analysis of the RecE pathway of genetic recombination in Escherichia coli K-12. Journal of Bacteriology 145, 521-532.

Hickson, I. D., Robson, C. N., Atkinson, K. E., HutTon, L. \& EMmERSON, P. T. (1985). Reconstitution of RecBC DNase activity from purified Escherichia coli RecB and RecC proteins. Journal of Biological Chemistry 260, 1224-1229.

HoRII, Z. I. \& ClarK, A. J. (1973). Genetic analysis of the RecF pathway to genetic recombination in Escherichia coli K12: isolation and characterisation of mutants. Journal of Molecular Biology 80, 327-344.

Howard-Flanders, P. \& Theriot, L. (1966). Mutants of Escherichia coli defective in DNA repair and genetic recombination. Genetics 53, 1137-1150.

IRINO, N., NAKaYAMA, K. \& NaKaYAMA, H. (1986). The recQ gene of Escherichia coli K 12: primary structure and evidence for SOS regulation. Molecular and General Genetics 205, 298-304.

JOSEPH, J. W. \& KolodNER, R. (1983). Exonuclease VIII of Escherichia coli. II. Mechanism of action. Journal of Biological Chemistry 258, 10418-10424.

Kolodner, R., Fishel, R. A. \& Howard, M. (1985). Genetic recombination of bacterial plasmid DNA: Effect of RecF pathway mutations on plasmid recombination in Escherichia coli. Journal of Bacteriology 163, 1060-1066.

Kushner, S. R., Nagaishi, H., Templin, A. \& Clark, A. J. (1971). Genetic recombination in Escherichia coli: the role of Exonuclease I. Proceedings of the National Academy of Sciences of the United States of America 68, 824-827.

Kushner, S. R., Nagaishi, H. \& Clark, A. J. (1972). Indirect suppression of $\operatorname{rec} B$ and $\operatorname{rec} C$ mutations by exonuclease I deficiency. Proceedings of the National Academy of Sciences of the United States of America 69, 1366-1370.

Kushner, S. R., Nagaishi, H. \& Clark, A. J. (1974). Isolation of exonuclease VIII : the enzyme associated with the $s b c A$ indirect suppressor. Proceedings of the National Academy of Sciences of the United States of America 71, 3593-3597.

LLOYD, R. G. \& BUCKMAN, C. (1985). Identification and genetic analysis of $s b c C$ mutations in commonly used $\operatorname{rec} B C \operatorname{sbc} B$ strains of Escherichia coli $\mathrm{K}-12$. Journal of Bacteriology 164, 836-844.

Lloyd, R. G. \& Thomas, A. (1983). On the nature of the RecBC and RecF pathways of conjugal recombination in Escherichia coli. Molecular and General Genetics 190, 156-161.
Lloyd, R. G. \& Thomas, A. (1984). A molecular model for conjugational recombination in Escherichia coli K12. Molecular and General Genetics 197, 328-336.

Lloyd, R. G., Low, B., Godson, G. N. \& Birge, E. A. (1974). Isolation and characterisation of an Escherichia coli $\mathrm{K} 12$ mutant with a temperature-sensitive RecA $^{-}$phenotype. Journal of Bacteriology 120, 407415.

Lloyd, R. G., Picksley, S. M. \& Prescott, C. (1983). Inducible expression of a gene specific to the RecF pathway for recombination in Escherichia coli K12. Molecular and General Genetics 190, 162-167.

Lloyd, R. G., Benson, F. E. \& Shurvinton, C. E. (1984). Effect of ruv mutations on recombination and DNA repair in Escherichia coli. Molecular and General Genetics 194, 303-309.

Lloyd, R. G., Evans, N. P. \& Buckman, C. (1987). Formation of recombinant lac $Z^{+}$DNA in conjugational crosses with a $\operatorname{rec} B$ mutant of Escherichia coli $\mathrm{K} 12$ depends on $\mathrm{recF}$, recJ and recO. Molecular and General Genetics (in the Press).

LovetT, S. J. \& ClaRK, A. J. (1983). Genetic analysis of regulation of the RecF pathway of recombination in Escherichia coli K-12. Journal of Bacteriology 153, 1471-1478.

LovetT, S. J. \& CLARK, A. J. (1984). Genetic analysis of the recJ gene of Escherichia coli K-12. Journal of Bacteriology 157, 190-196.

Nakayama, H., Nakayama, K., Nakayama, R., IRINo, N., Nakayama, Y. \& Hanawalt, P. C. (1984). Isolation and genetic characterization of a thymineless death-resistant mutant of Escherichia coli K 12: Identification of a new mutation (recQI) that blocks the RecF recombination pathway. Molecular and General Genetics 195, 474-480.

OtSUJi, N., IYEHARA, H. \& Hideshima, Y. (1974). Isolation and characterization of an Escherichia coli ruv mutant which forms nonseptate filaments after low doses of ultraviolet light irradiation. Journal of Bacteriology 117, 337-344.

Picksley, S. M., Attfield, P. V. \& Lloyd, R. G. (1984a). Repair of DNA double-strand breaks in Escherichia coli $\mathrm{K} 12$ requires a functional recN product. Molecular and General Genetics 195, 267274.

Picksley, S. M., Lloyd, R. G. \& Buckman, C. $(1984 b)$. Genetic analysis and regulation of inducible recombination in Escherichia coli K12. Cold Spring Harbor Symposia on Quantitative Biology XLIX, 469474.

Ponticelli, A. S., Schultz, D. W., Taylor, A. F. \& Smith, G. R. (1985). Chi-dependent DNA strand cleavage by RecBC enzyme. Cell 41, 145-151.

RadDING, C. M. (1982). Homologous pairing and strand exchange in genetic recombination. Annual Review of Genetics 16, 405-437.

Shurvinton, C. E. \& Lloyd, R. G. (1982). Damage to DNA induces expression of the ruv gene of Escherichia coli. Molecular and General Genetics 185, $352-355$.

Shurvinton, C. E., Lloyd, R. G., Benson, F. E. \& AtTfield, P. V. (1984). Genetic analysis and molecular cloning of the Escherichia coli ruv gene. Molecular and General Genetics 194, 322-329. 
Silhavy, T. J., Berman, M. L. \& Enquist, L. W. (1984). Experiments with Gene Fusions. Cold Spring Harbor, New York: Cold Spring Harbor Laboratory.

TAYLOR, A. \& SMITH, G. R. (1985). Substrate specificity of the DNA unwinding activity of the RecBC enzyme of Escherichia coli. Journal of Molecular Biology 185, 431-443.

Taylor, A. F., Schultz, D. W., Ponticelli, A. S. \& SMITH, G. R. (1985). RecBC enzyme nicking at Chi sites during DNA unwinding: location and orientation-dependence of the cutting. Cell 41, 153-163.

ThOMAS, A. \& LLOYD, R. G. (1980). Altered regulation of the rec $A$ gene in Escherichia coli strains carrying a recA-linked suppressor of lexA. Molecular and General Genetics 179, 355-358.

Walker, G. C. (1984). Mutagenesis and inducible responses to deoxyribonucleic acid damage in Escherichia coli. Microbiological Reviews 48, 60-93. Willetts, N. \& Wilkins, B. (1984). Processing of plasmid DNA during bacterial conjugation. Microbiological Reviews 48, 24-41.

Willis, D. K., Satin, L. H. \& Clarke, A. J. (1985). Mutation-dependent suppression of recB2I recC22 by a region cloned from the Rac prophage of Escherichia coli K12. Journal of Bacteriology 162, 1166-1172. 